\title{
Specification of drug administration in geriatric patients within the competences of the nurse
}

\author{
Pavol Jozef Šafárik University in Košice, Faculty of Medicine, Department of the Nursing Care, Slovakia
}

lucia.dimunova@upjs.sk,jana.rakova@upjs.sk

\section{Дімунова Л., Ракова Я. \\ Особливості прийому ліків у геріатричних хворих в межах компетенції медсестри}

Університет імені Йозефа Шафарика в м. Кошице, медичний факультет, відділ сестринської допомоги, м. Кошице, Словаччина
Димунова Л., Ракова Я.

Особенности приема лекарств у гериатрических больных в пределах компетенции медсестры

Университет имени Йозефа Щафарика в г. Кошице, медицинский факультет, отделение сестринской помощи, г. Кошице, Словакия

\section{Introduction}

As the world's population ages, global health care systems will face the burden of chronic diseases and polypharmacy use among older adults [1]. According to WHO there are about 600 million people aged 60 and over worldwide; this total will double by 2025 and will reach virtually two billion by 2050 [2]. Geriatrics deals with the so called "aging" phenomenon. The framework of geriatrics includes areas such as clinical geriatrics, social geriatrics, pharmacology in geriatrics and geriatric nursing $[3,4]$.

Geriatric nursing is one of the nursing disciplines; it includes the competences of nursing practice and holistic approach to the care of these patients [5]. The nurse is expected to perform roles in providing individualized nursing care with respect to the biological, psychological and social specifics of geriatric patients. The nursing profession also requires critical thinking, high-level expertise, and practical skills [6]. One of the areas of nursing care is also pharmacotherapy. As a part of pharmacological treatment, the nurse administers medicine on behalf of the doctor's authorization. She performs various interventions, which depend on the type of healthcare facility, health, mental and socio-economic condition. The nurse should have adequate knowledge and skills needed to work with seniors. The nurse is obliged to master the rules and proper techniques of drug administration, drug handling, and storage [7]. In many cases, the nurse provides the patient with a feedback on understanding the proper use of medication. The nurse participates in the education process and her work is also important in increasing of the patient's compliance [8]. The positive effect of nursing interventions in primary care focused on drug use in patients with an average age of 72 years was also demonstrated by a study of Steinman et al. [9]. The positive role of the nurse was similarly proved by an Egyptian study by Mohamed et al. [10], where seniors also demonstrated better knowledge of drug administration and use after nurse interventions. The pharmacotherapy risk and the occurrence of adverse reactions in elderly patients are increased. The safety of drug treatment is directly related to risk perception and is one of the most important quality principles of pharmacotherapy. Problems that accompany treatment of the elderly are: economic cost, multimorbidity and polypharmacology associated with drug side effects, insufficient diagnosis, non-compliance of the geriatric patient [11]. The nurse must also be aware of the possible risks associated with medications in order to be able to effectively provide quality nursing care in cooperation with a doctor and a pharmacist $[12,13]$.

\section{Methodology}

The aim of the study was to find out how nurses perceive the specifics of pharmacotherapy in geriatric patients. Subsequently, it attempted to identify the most common problems within pharmacotherapy and patients' safety in clinical practice.

The group of respondents was intentional; it consisted of 48 nurses working in a facility providing nursing care for geriatric patients in Slovakia. The selection criteria were at least one year of nurses' working experience, practice skills, current employment in the ward with geriatric patients and willingness to cooperate. The questionnaire was anonymous.

We used a self-designed questionnaire to collect data for the survey. The questions in the questionnaire were divided into two areas: the area of intervention of nurses in pharmacotherapy and the area of problems related to pharmacotherapy. Empirical data collection was carried out from January to March 2020. 50 nurses were contacted in the facility, 48 questionnaires were returned, which represents a $96 \%$ return. The obtained data are processed in Microsoft Excel software into tables and graphs. We used methods of descriptive statistics to describe the results. 


\section{Results}

The average length of practice of nurses was $12.77 \pm 2.11$ years. The first part focused on identifying the interventions that nurses implement in the framework of pharmacotherapy in geriatric patients. Table 1 shows the specific interventions and statements of nurses on their application in clinical practice. Nurses are actively involved in the preparation and administration of drugs and actively cooperate with the doctor. As for monitoring the effects of medication by nurses, we recorded 19 responses that said 'no' or 'occasionally', which we assess as incorrect. Ordering medicine is largely the responsibility of a head nurse, which corresponds to the marked answers of the nurses.

The frequency of the responses of nurses $(n=40)$ related to the communication of seniors indicates shortcomings in this area, similarly to the area of education of family members $(n=41)$.

Table 1. Interventions of nurses in pharmacotherapy

\begin{tabular}{|c|c|c|c|c|c|c|}
\hline \multirow{2}{*}{ Options } & \multicolumn{2}{|c|}{ Yes } & \multicolumn{2}{|c|}{ No } & \multicolumn{2}{|c|}{ Occasionally } \\
\hline & $\mathbf{n}$ & $\%$ & $\mathbf{n}$ & $\%$ & $\mathbf{n}$ & $\%$ \\
\hline Medicine preparation & 39 & 81 & 1 & 2 & 8 & 17 \\
\hline Medicine administration & 39 & 81 & 1 & 2 & 8 & 17 \\
\hline Monitoring of medicine effects & 29 & 60 & 9 & 19 & 10 & 21 \\
\hline Informing doctor about health state & 34 & 71 & 0 & 0 & 14 & 29 \\
\hline Cooperation with doctor & 41 & 85 & 0 & 0 & 7 & 15 \\
\hline Ordering of medicine & 7 & 15 & 33 & 68 & 8 & 17 \\
\hline Communication with senior about pharmacotherapy & 8 & 17 & 28 & 58 & 12 & 25 \\
\hline Education of senior and family members & 7 & 15 & 30 & 62 & 11 & 23 \\
\hline
\end{tabular}

In the next part, we focused on the most common problems that nurses encounter in pharmacotherapy in geriatric patients. Pharmacotherapy is one of the important indicators of patient safety.

We analysed the statements of the nurses about the most common problems they encounter in the execution of their profession. The most frequent response was noncooperation of seniors in administration of drugs, which was reported by $37 \%(n=35)$ of nurses, the option "negative attitude to treatment" was reported by $20 \%(n=19)$ of nurses.

Distrust of medical staff was reported in $22 \%(n=21)$ of respondents and as for the option "patient's mental state", $21 \%$ $(n=20)$ of nurses indicated such answer. This implies that the most frequently indicated responses were non-cooperation and distrust of medical staff. These options are considered by nurses to be a common problem in relation to geriatric patient.

We formulated questions for the nurses in a specific way to find out which mistakes in medicine administration they consider to be the most severe. The items are processed in Table 2. The data suggest the answers "administration of wrong dose" and "exchange of medicine" are indicated the most often. Based on the respondents' answers, we can conclude that the nurses possess knowledge about the risk factors of pharmacotherapy in relation to patient safety.

Table 2. Error possibilities in pharmacotherapy

\begin{tabular}{|l|l|l|}
\hline \multicolumn{1}{|c|}{ Options } & n & \% \\
\hline Exchange of medicine & 31 & 31 \\
\hline Exchange of patient & 24 & 23 \\
\hline Administration of wrong dose & 33 & 33 \\
\hline Failure to administer medicine & 13 & 13 \\
\hline
\end{tabular}

\section{Discussion}

The interventions by which nurses engage in pharmacotherapy administrated to geriatric patients have their own specifics. In our monitored group, a high percentage of nurses are dedicated to a thorough preparation and administration of drugs. The results are in agreement with a study performed in Slovakia and the Czech Republic in connection with the competencies of nurses in pharmacotherapy [14]. We recorded a low percentage of responses among nurses in the field of education and communication, what may have an impact on successful treatment. Most nurses state workload and insufficient number of staff as their reason for not devoting enough time to education and communication. Senior education has a significant position in nursing care. It is similarly important in the field of pharmacotherapy with its peculiarities in the elderly. For education of the elderly to be effective, the educator must have general knowledge about aging, the changes that are taking place in old age and about the educational process. The seniors are educated about pharmacotherapy most often by healthcare professionals involved in their treatment; this includes doctors, nurses and pharmacists. Education for the elderly focuses on pharmacotherapy instruction, medication use, and possible side effects. It is important to assess the level of seniors' knowledge and skills related to prescribed medicine as well as over-the-counter drugs [15]. The positive effect of nursing education on the pharmacotherapy topic is also discussed in the study of Dilles et al. [16]. In education, it is important that the relatives who help the senior in care are also given instructions. One is supported systems are information systems. For many, their use is beneficial in terms of saving time and ease of accessibility [17]. In this context the term health literacy is 
often being mentioned [18] in the process of education in planning and preparation of nursing interventions. Nurses can minimize shortcomings in primary and secondary care by adapting the content and methods of communicating health information in the interview. Forms of correct reinterpretation of information to patients can contribute to understanding the content of the information and lower occurrence of errors caused by lack of knowledge.

A quality healthcare is unthinkable without communication between the nurse and the geriatric patient. With proper conversation, knowledge and the use of communication skills, the nurse can obtain information, positively influence the patients, educate them, motivate them and persuade them to cooperate.

In our survey, nurses identified the most common problems related to pharmacotherapy in clinical practice as follows: non-cooperation of seniors in adhering to the treatment, distrust of medical staff, negative attitude of the patient and mental state. All of these issues are intertwined and interrelated. Because if the mental state of a senior is bad, he or she is not willing to cooperate or does not trust the medical staff, what causes negative attitude to the treatment and thus it follows that he/she is not cooperating. Similar findings are reported in the study by Zrubáková et al., [14] where they identified fear of patients as a significant factor associated with pharmacotherapy. Fear creates a barrier that can trigger problems with pharmacotherapy and as a result it causes difficulties in cooperation between the patient and the healthcare professionals. It causes negative behaviour, nervousness, distrust, worries; it worsens the patient's mental state, increases tension. This confirms to us that the most common problems mentioned by the nurses in our focus group are distrust and non-cooperation
With regards to the patient safety connected with pharmacotherapy, we found in our cohort that nurses perceive as a possible risk exchange of medicine or administration of a wrong dose. These errors are very serious and great care is constantly taken to prevent them as much as possible. At present, nurses prepare medications manually according to the doctor's schedule and instructions, then assign and introduce them to a specific senior. This method requires substantial amount of time. In various European countries, hospitals are switching to electronic prescribing and dispensing of medicine to patients - Drug Dosage Monitoring System (MSDL) [19]. This saves time which the nurse can dedicate otherwise to the patients while reducing the error rate in allocating drugs or administering a wrong dose of medication. The safety of medicine practices is also overseen by the Institute for Safe Medication Practice in the form of Guidelines, which relate to the safe use of specific drug technologies and the treatment of at-risk patient communities, including the elderly.

\section{Conclusions}

Pharmacotherapy is one of the important competencies of nurses. They apply its principles in execution of their profession every day. Our effort was to make an inquiry into clinical practice and obtain the views of nurses. All in all, we can conclude that nurses apply their competencies in the field of pharmacotherapy very actively and responsibly, taking into account the specifics of geriatric patients. We have identified slight shortcomings in the field of education and communication, which we consider important and perceive it as an incentive for postgraduate education of nurses. We also regard the expressed opinions of nurses on possible risks to patient safety to be serious. It is currently a much-discussed topic, and our findings confirm its validity.

\section{References}

1. Lee, J.K., Alshehri, S., Kutbi, H., Martin, J.R. Optimizing pharmacotherapy in elderly patients: the role of pharmacists. Integr Pharm Res Pract., 2015; 4:101-111. doi: 10.2147/IPRP.S70404.

2. WHO. Ageing and life course. [online] 2018. Available at: https://www.who.int/ageing/primary_health_care/en/

3. Belovičová, M., Vansáč, P. Selected aspects of medical and social care for long-term ill persons. Towarzystwo Slowaków w Polsce, Kraków, 2019, 153 p. ISBN 978-83-811110-9-6.

4. Mauk, K.L. Gerontological nursing competencies for care. 4th ed. Burlington, MA: Jones \& Barlett Learning 2017.

5. Grešš Halász, B., Hudáková, A., Kaščáková, M. Gerontological advanced nurse practitioners in senior care. General Practicioner, 2019; 99(5):210-214.

6. Dimunová, L., Mohnyánszki, F., Raková, J. Pracovná zát’až sestry. Praha: powerptint. 2018. s. 75. ISBN 978-807568-097-6.

7. Pilotto, F., Martin, F. Comprehensive geriatric assessment. E-book. Springer nature publishing company, 1st ed., 2018; p. 182. Available at: http://www.twirpx.com.file.

8. Zrubáková, K., Krajčík, Š., et al. Pharmacotherapy in geriatrics. Grada publishing, a.s., 2016. 224 p. ISBN 978-80247-5229-7.

9. Steinman, M.A., Low, M., Balicer, R.D., Shadmi E. Impact of a nurses-based intervention on medication outcomes in ulnerable older adults. BMC Geriatr. 2018; 18(1):207. doi: 10.1186/s12877-018-0905-1.

10. Mohamed, N.A., Hafez, S.H., Shrief, S.E. Nursing based intervention to optimize knowledge and practices of old age patients about polypharmacy. IOSR-JNHS, 2019; 8(1):29-37.

11. Hegyi, L. Long-term or health-social care? Geriatria, 2015; 1:7-13. ISSN 1335-1850.

12. Petrovič, M., Sommers, A., Onder, G. Optimisation of geriatric pharmacotherapy: role of multifaceted cooperation in the hospital setting. Drugs Aging. 2016. doi:10.1007/s40266-016-0352-7. 
13. Bednarek, A., Zarzycka, D. Trends in vaccinology education of nurses in Poland. Medical and Biological Sciences, 2015.29(1):5-11. doi: http://dx.doi.org/10.12775/MBS.2015.001.

14. Zrubáková, K., Magerčiaková, M., Teperová, M. New trends in the education and practice of health professionals. "Pharmacotherapy of seniors and its problems in Slovakia and the Czech Republic" Prohuman [online]. Available at https://www.prohuman.sk/files/Nove-trendy-vo-vzdelavani-a-praxi-zdrav-prac-2014.pdf.

15. Zanovitová, M., Kurucová, R., Tomagová, M., Boriková, I., Miertová, M. Selected aspects of health care for the elderly. Martin: UK JLF, 2015. 83 s. ISBN: 978-80-89544-93-6.

16. Dilles, T., Stichele R.V., van Rompaey, B., van Bortel, L., Elseviers, M. Nurses' practices in pharmacotherapy and their association with educational level. Journal of Advanced Nursing, 2010. 66(5):1072-1079. doi.org/10.1111/j.13652648.2010.05268.x.

17. Popovičová M., Belovičová M. eHealth healthcare electronization in Slovakia. ISSN 2077-6594. Ukraine. Nation's Health. 2020.1 (58): 23-27. doi 10.24144/2077-6594.1.2020.197015.

18. Dingová, M., Jakubcová, T. Health Literacy - New Concept for Nursing Practice. Ošetrovatel'stvo: teória, výskum, vzdelávanie, 2011;1(1):34-41.

19. Tóth, M. Monitoring system for drug delivery suitable for elderly people who have been using medicines for long periods in social care facility and at home environment [online]. Prohuman, 2020. Available at: https://www.prohuman.sk/ socialne-sluzby/monitorovaci-system-davkovania-liekov-msdl.

Дата надходження рукопису до редакції: 04.03.2020 p.

Aim. The study's objective was to obtain the views of nurses on the application of competencies in the field of pharmacotherapy in geriatric patients in clinical practice. Subsequently, it attempted to identify the most common problems that nurses encounter in relation to pharmacotherapy and safety of geriatric patients.

Material and methods. The group consisted of 48 nurses working in a facility providing care for geriatric patients. A non-standardized questionnaire was used for data collection, which included two areas: the area of intervention of nurses in pharmacotherapy and the area of problems related to pharmacotherapy.

Results. Nurses apply their competencies focused on pharmacotherapy, especially in the preparation and administration of drugs. The answers of nurses in the field of education $(62 \%)$ and communication $(58 \%)$ related to pharmacotherapy in the elderly can be considered insufficient. The most common problems that nurses encounter in clinical practice are non-cooperation of seniors, their distrust and negative attitude towards treatment. Nurses identified incorrect dosing and drug substitution as potential errors that could compromise the safety of the geriatric patient.

Conclusions. Based on the results of our research, we can state that nurses actively apply their competencies in pharmacotherapy, taking into account the specifics of geriatric patient care. The shortcomings we have identified in the field of education and communication related to pharmacotherapy indicate the need to support the education and practical training of nurses' skills. Further attention needs to be paid to the safety of the patient in pharmacotherapy.

Key words: geriatric patient, pharmacotherapy, education, nurses, safety patients.

Мета дослідження - вивчити думку медсестер щодо застосування компетенцій в області фармакотерапії у геріатричних пацієнтів в клінічних умовах. Згодом виявити найбільш поширені проблеми, 3 якими стикаються медсестри в рамках фармакотерапії і безпеки пацієнтів із захворюваннями шлунку.

Матеріали та методи. Група дослідження складалася 348 медсестер, які працюють в установі, що забезпечує догляд за геріатричними пацієнтами. Для збору даних використовувалася нестандартизована анкета, яка включала дві області: область втручання медсестер в фармакотерапію і область проблем, пов'язаних з фармакотерапією.

Результати. Медсестри застосовують свої компетенції, орієнтовані на фармакотерапію, особливо в області підготовки і прийому ліків. Інформованість медсестер в галузі освіти (62\%) і комунікації (58\%), пов’язаних 3 фармакотерапії у літніх людей, можна вважати недостатніми. Найбільш поширені проблеми, 3 якими медсестри стикаються в клінічній практиці, - це відсутність взаємодії з людьми похилого віку, їх недовіру і негативне ставлення до лікування. Медсестри визначили введення неправильної дози препарату і заміну препарату як потенційно можливі помилки, які можуть поставити під загрозу безпеку геріатричного пацієнта.

Висновки. Виходячи 3 результатів нашого дослідження, ми можемо констатувати, що медсестри активно застосовують свої компетенції в фармакотерапії з урахуванням специфіки догляду за геріатричними пацієнтами. Недоліки, які ми виявили в галузі освіти і комунікації, пов’язані з фармакотерапією, вказують на необхідність підтримки навчання і практичного підготовки медсестер. Необхідно і далі приділяти велику увагу безпеці пацієнтів під час фармакотерапії.

Ключові слова: літній (геріатричний пацієнт), фармакотерапія, освіта, медсестри, безпека пацієнтів.

Цель исследования - изучить мнение медсестер относительно применения компетенций в области фармакотерапии у гериатрических пациентов в клинических условиях. Впоследствии выявить наиболее 
распространенные проблемы, с которыми сталкиваются медсестры в рамках фармакотерапии и безопасности пациентов с заболеваниями желудка.

Материалы и методы. Группа исследования состояла из 48 медсестер, работающих в учреждении, обеспечивающем уход за гериатрическими пациентами. Для сбора данных использовалась нестандартизированная анкета, которая включала две области: область вмешательства медсестер в фармакотерапию и область проблем, связанных с фармакотерапией.

Результаты. Медсестры применяют свои компетенции, ориентированные на фармакотерапию, особенно в области подготовки и приема лекарств. Информированность медсестер в области образования (62\%) и коммуникации (58\%), связанных с фармакотерапией у пожилых людей, можно считать недостаточными. Наиболее распространенные проблемы, с которыми медсестры сталкиваются в клинической практике, - это отсутствие взаимодействия с пожилыми людьми, их недоверие и негативное отношение к лечению. Медсёстры определили введение неправильной дозы препарата и замену препарата как потенциально возможные ошибки, которые могут поставить под угрозу безопасность гериатрического пациента.

Выводы. Исходя из результатов нашего исследования, мы можем констатировать, что медсестры активно применяют свои компетенции в фармакотерапии с учетом специфики ухода за гериатрическими пациентами. Недостатки, которые мы выявили в области образования и коммуникации, связанные с фармакотерапией, указывают на необходимость поддержки обучения и практической подготовки медсестер. Необходимо и далее уделять большое внимание безопасности пациентов во время фармакотерапии.

Ключевые слова: пожилой (гериатрический пациент), фармакотерапия, образование, медсестры, безопасность пациентов.

Конфлікт інтересів: відсутній.

Conflicts of interest: authors have no conflicts of interest to declare.

Ethical aspects: the research followed ethical guidelines in accordance with the Helsinki Declaration of 1975, as revised on 2013.

\section{Відомості про авторів}

Dimunová Lucia - PhD., doc., PhDr. - teacher, Pavol Jozef Šafárik University in Košice, Faculty of Medicine, Department of The Nursing Care; Tr. SNP 1, Košice, Slovakia.

+421 (55) 234-32-92, lucia.dimunova@upjs.sk.

Raková Jana - PhD., PhDr. - teacher, Pavol Jozef Šafárik University in Košice, Faculty of Medicine, Department of The Nursing Care; Tr. SNP 1, Košice, Slovakia.

jana.rakova@upjs.sk. 